\title{
Acetyl-CoA carboxylase activity in Helicobacter pylori and the requirement of increased $\mathrm{CO}_{2}$ for growth
}

\author{
Brendan P. Burns, ${ }^{1}$ Stuart L. Hazell ${ }^{1}$ and George L. Mendz ${ }^{2}$ \\ Author for correspondence: Stuart L. Hazell. Tel: +612385 2040. Fax: +6123136528.
}

Schools of Microbiology and Immunology ${ }^{1}$ and Biochemistry and Molecular Genetics², The University of New South Wales, Sydney 2052 .

Australia

\begin{abstract}
A biotinylated acetyl-CoA carboxylase from the microaerophilic bacterium Helicobacter pylori was partially purified and characterized. The approximate molecular mass of the native enzyme was estimated at $235 \mathrm{kDa}$ by native PAGE. A single band corresponding to approximately $24 \mathrm{kDa}$ was detected by SDS-PAGE, suggesting that the native enzyme is a multi-protein complex. The protein was isolated from the soluble fraction of the cell. Catalytic activity was acetyl-CoA-dependent and inhibited by avidin but unaffected by avidin pretreated with excess biotin. The end-product of the reaction was identified as malonyl-CoA and the reaction was shown to be reversible by NMR spectroscopy. The activity of the enzyme was $0.29 \mu \mathrm{mol} \mathrm{min}^{-1}$ (mg protein) ${ }^{-1}$. The $V_{\max }$ for bicarbonate was calculated at $0.73 \mu \mathrm{mol} \mathrm{min}^{-1}$ (mg protein) ${ }^{-1}$, and the affinity of the enzyme for this substrate was relatively low, with an apparent $K_{\mathrm{m}}$ of $16.6 \mathrm{mM}$. These data provide the first evidence of a possible physiological role for the requirement of high levels of $\mathrm{CO}_{2}$ for growth in vitro of this bacterium.
\end{abstract}

Keywords: Helicobacter pylori, acetyl-CoA carboxylase, $\mathrm{CO}_{2}$

\section{INTRODUCTION}

Helicobacter pylori is now recognized as the causative agent of chronic gastritis and a significant proportion of duodenal and gastric ulcers (Marshall \& Warren, 1984; Goodwin et al., 1986). Recently, the World Health Organization declared $H$. pylori to be a group 1 carcinogen because of its role in the development of gastric carcinoma (IARC, 1994). Although recent studies have begun to characterize the nutritional requirements of this pathogen (Nedenskov, 1994; Reynolds \& Penn, 1994), an understanding of why elevated levels of $\mathrm{CO}_{2}$ are required by the bacterium for growth has been lacking.

Early studies of the need for $\mathrm{CO}_{2} / \mathrm{HCO}_{3}^{-}$(in solution at physiological $\mathrm{pH}$ the equilibrium favours the formation of bicarbonate) in bacteria that grow at higher partial pressures of $\mathrm{CO}_{2}$ showed that the compound enters into the synthesis of essential metabolites via carboxylation (Lyman et al., 1947; Ajl \& Werkman, 1948). An indication of the probable importance of carboxyl utilization in $H$. pylori physiology was the finding that ${ }^{14} \mathrm{C}$-labelled $\mathrm{HCO}_{3}^{-}$ was incorporated during the growth of the bacterium (Mendz et al., 1994b), suggesting the presence of carbamoyl-phosphate synthetase. However, it is difficult to envisage the activity of this enzyme as the sole cause for the need of high $\mathrm{CO}_{2}$ concentrations for the growth of $\mathrm{H}$. pylori. It is more likely that bicarbonate is required for a number of cellular activities in this micro-organism.

It has been proposed by Cox \& Baugh (1977) that some micro-organisms that require an environment enriched in $\mathrm{CO}_{2}$ may possess enzymes with a high $K_{\mathrm{m}}$ in relation to the specific substrate $\mathrm{CO}_{2} / \mathrm{HCO}_{3}^{-}$; that is, a low affinity for $\mathrm{CO}_{2} / \mathrm{HCO}_{3}^{-}$. Studies of $\mathrm{CO}_{2} / \mathrm{HCO}_{3}^{-}$-metabolizing enzymes in $H$. pylori may reveal such a mechanism or other unique properties of such enzymes that would help us understand the need for an enriched $\mathrm{CO}_{2}$ environment for growth of this organism in vitro. The identification of a biotinylated protein in this bacterium - a group of proteins known to be involved in bicarbonate metabolism in other organisms - presented an opportunity to study one component of $\mathrm{CO}_{2} / \mathrm{HCO}_{3}^{-}$metabolism in $\mathrm{H}$. pylori.

The results presented here report the partial purification and biochemical characterization of acetyl-CoA carboxylase in $H$. pylori. After putatively identifying the protein by size comparisons with other biotinylated proteins, the activity and kinetics of the enzyme were determined in relation to bicarbonate requirements. A preliminary communication of part of this work has been presented previously by Burns et al. (1994). 


\section{METHODS}

Substrates and reagents. $\mathrm{NaH}^{14} \mathrm{CO}_{3} \quad\left(0 \cdot 1 \mathrm{mCi} \mathrm{mmol}^{-1}\right.$; $3.7 \mathrm{MBq} \mathrm{m^{-1 }}{ }^{-1}$ ) was purchased from Amersham Life Sciences. Avidin alkaline phosphatase conjugate, 5-bromo-4-chloro-3indolyl phosphate and $p$-nitroblue tetrazolium chloride were obtained from Bio-Rad Laboratories. Sephacryl S-300 HR was from Pharmacia. ATP, d-biotin, malonyl-CoA and molecular mass markers were obtained from Sigma, and acetyl-CoA was from Boehringer Mannheim. Blood Agar Base no. 2 was from Oxoid. All other reagents were of analytical grade.

Strains and growth conditions. H. pylori strains NCTC 11639 , UNSW P10, UNSW RU1, N6 and a recent clinical isolate, strain 921007, were grown on Blood Agar Base no. 2 plates, supplemented with $5-7 \%(\mathrm{v} / \mathrm{v})$ horse blood. The medium was supplemented with fungizone $\left(2 \mu \mathrm{g} \mathrm{m}^{-1}\right)$, trimethoprim $(5 \mu \mathrm{g}$ $\left.\mathrm{ml}^{-1}\right)$, polymyxin $\mathrm{B}\left(2 \cdot 5 \mu \mathrm{g} \mathrm{ml}^{-1}\right)$ and vancomycin $\left(10 \mu \mathrm{g} \mathrm{m}^{-1}\right)$. $H$. pylori cultures were incubated in a Stericult incubator (Forma Scientific) in an atmosphere of $10 \% \mathrm{CO}_{2}$ in air, $95 \%$ relative humidity, at $37^{\circ} \mathrm{C}$. Cells were passaged every $36-48 \mathrm{~h}$, checked for purity under phase-contrast microscopy and tested for positive urease and catalase activity.

Preparation of cell-free extracts. Cells were harvested in exponential phase (approximately $36 \mathrm{~h}$ ) in $0.1 \mathrm{M}$ sodium phosphate buffer, $\mathrm{pH} 7 \cdot 2$ (PB), and centrifuged at $17000 \mathrm{~g}$ for $8 \mathrm{~min}$ at $6{ }^{\circ} \mathrm{C}$. The resulting pellet was washed twice and resuspended in approximately $5 \mathrm{ml} \mathrm{PB}$. Cells were disrupted by two cycles through a French pressure cell, or by twice freezing in liquid nitrogen and thawing cell suspensions. The lysed extract was then centrifuged at $27000 \mathrm{~g}$ for $8 \mathrm{~min}$ at $6{ }^{\circ} \mathrm{C}$. The resulting supernatant was filtered through a $0.2 \mu \mathrm{m}$ pore-size membrane filter and the filtrate collected. Unless otherwise stated, this filtrate represents the 'cell-free extract' described in later sections.

Cell fractionation. To investigate the cellular location of the biotinylated protein, $\mathrm{H}$. pylori cell-free extracts were centrifuged at $100000 \mathrm{~g}$ for $60 \mathrm{~min}$ at $4{ }^{\circ} \mathrm{C}$ to separate the membranes from the cytosol. The supernatant was removed, and the resulting membrane pellet was resuspended in PB. All bacterial fractions were stored at $-20{ }^{\circ} \mathrm{C}$ until required.

Protein determination. Protein concentrations were estimated by the bicinchoninic acid method using a microtitre-plate-based protocol (Pierce Chemical).

Purification of biotinylated protein. The cell-free extract (approximately $3.5 \mathrm{mg} \mathrm{ml}^{-1}$ ) was applied to a $\mathrm{K} 26 / 100$ gelfiltration column containing Sephacryl S-300 HR. A liquid phase of PB at a flow rate of $1.2 \mathrm{ml} \mathrm{min}$-1 was used to elute proteins. Fractions were taken at $4 \mathrm{~min}$ intervals and an elution profile was obtained by scanning the eluate at $280 \mathrm{~nm}$ with a Vicord 2138 spectrophotometer (LKB Bromma).

Column fractions testing positive for biotinylated proteins using the avidin-linked Western blot were pooled, then concentrated by ultrafiltration through a $100 \mathrm{kDa}$ molecular mass cut-off filter (Millipore) using an Amicon 8050 filtration unit. Proteins retained by the filter were resuspended by washing off the filter in $\mathrm{PB}$, and the filtrate passed through a $30 \mathrm{kDa}$ cutoff membrane filter (Amicon). The proteins retained on this filter were resuspended in $\mathrm{PB}$, and the filtrate and retentate from each step were analysed for the presence of biotinylated proteins.

A monomeric avidin column was prepared and the protein samples were loaded and eluted according to Beaty \& Lane (1982) and Gravel et al. (1980) using an Affinity Pak of immobilized avidin (Pierce).
SDSPAGE. Electrophoretic analysis of fractionated proteins was performed using a discontinuous buffer system, based on an established procedure (Laemmli, 1970). Protein samples (approximately $1 \mathrm{mg} \mathrm{m}^{-1}$ ) were denatured and reduced by mixing in a sample buffer that contained $2 \%(\mathrm{v} / \mathrm{v})$ SDS and $0.05 \%(\mathrm{v} / \mathrm{v}) \beta$-mercaptoethanol then heated in a boiling water bath for $10 \mathrm{~min}$. Gels were initially stained with Coomassie Blue; however a more sensitive detection of proteins was achieved by employing a rapid silver stain (Neilan et al., 1994). Proteins of known molecular size, bovine albumin $(66 \mathrm{kDa})$, egg albumin $(45 \mathrm{kDa})$, glyceraldehyde-3-phosphate dehydrogenase $(36 \mathrm{kDa})$, carbonic anhydrase $(29 \mathrm{kDa})$, trypsinogen $(24 \mathrm{kDa})$ and trypsin inhibitor $(20.1 \mathrm{kDa})$, were used to construct a standard curve.

Native molecular mass determination by electrophoresis. Non-reducing and non-denaturing gel electrophoresis was performed by modifying the procedure of Laemmli (1970). Separating gels were composed of $8 \%(\mathrm{w} / \mathrm{v})$ acrylamide and SDS was omitted from all solutions. Protein mixtures were not boiled or reduced and samples were electrophoresed as for SDSPAGE. Markers were: $\beta$-amylase $(200 \mathrm{kDa})$, alcohol dehydrogenase $(150 \mathrm{kDa}), \beta$-galactosidase $(116 \mathrm{kDa})$, phosphorylase $\mathrm{B}$ $(97 \cdot 4 \mathrm{kDa})$, bovine albumin $(66 \mathrm{kDa})$ and egg albumin $(45 \mathrm{kDa})$.

Western blotting. After electrophoresis, proteins were transferred to a blotting membrane in a semi-dry electroblotting (SDE) transfer system. Transfer was carried out in a MilliblotSDE Transfer System (Millipore), based on an established protocol (Towbin et al., 1979). After transfer, membrane-bound biotinylated proteins were detected utilizing an avidin-linked enzyme conjugate. Unoccupied protein-binding sites on the membrane were first blocked in TBS $(20 \mathrm{mM}$ Tris, $500 \mathrm{mM}$ $\mathrm{NaCl}, \mathrm{pH} 7.5)$ containing $3 \%(\mathrm{w} / \mathrm{v})$ gelatin. The membrane was then washed in $0.05 \%(\mathrm{v} / \mathrm{v})$ Tween-20 TBS (TTBS) for $10 \mathrm{~min}$. The blot was incubated for $1 \mathrm{~h}$ with avidin alkaline phosphatase conjugate $(1: 1000)$ in TTBS containing $1 \%$ gelatin. The membrane was then washed three times $(10 \mathrm{~min}$ each) in TTBS, followed by two washes ( $5 \mathrm{~min}$ each) in distilled water. After the final wash, $0.56 \mathrm{mM}$ 5-bromo-4-chloro-3indolyl phosphate and $0.48 \mathrm{mM} p$-nitroblue tetrazolium chloride were added to $10 \mathrm{mM}$ Tris $/ \mathrm{HCl}(\mathrm{pH} 9 \cdot 5)$ and incubated with the membrane until sharp purple bands appeared. Substrate development was stopped by rinsing in distilled water.

Radioactive tracer analysis. The acetyl-CoA carboxylase assay method used was based on that of Gregolin et al. (1966), and measured the incorporation of $\left[{ }^{14} \mathrm{C}\right]$ bicarbonate into an acidstable product, malonyl-CoA. The assay mixture contained the following components: ATP, $1 \mathrm{mM} ; \mathrm{NaH}^{14} \mathrm{CO}_{3}^{-}, 10 \mathrm{mM}$; $\mathrm{MgCl}_{2}, 1 \mathrm{mM}$; EDTA, $1 \mathrm{mM}$; acetyl-CoA, $1 \mathrm{mM}$; BSA, $2 \mathrm{mg}$ $\mathrm{ml}^{-1}$ (measurements at this concentration of bicarbonate were used to demonstrate enzyme activity before kinetic studies were conducted). The assay mixture was made to a final volume of $200 \mu \mathrm{l}$ with $\mathrm{PB}(\mathrm{pH} 7 \cdot 0)$. The reaction was initiated by adding either $H$. pylori lysates or cell-free extracts. Mixtures were incubated for $60 \mathrm{~min}$ at $37^{\circ} \mathrm{C}$.

The kinetics of the enzyme were studied by varying the concentration of bicarbonate and keeping acetyl-CoA and ATP saturating and constant $(1 \mathrm{mM})$. The data were fitted to the Michaelis-Menten equation using the program Enzyme Kinetics (Trinity Software), where the values of the kinetic parameters and standard errors are automatically calculated. Reactions were terminated by the addition of formic acid $(0.1 \mathrm{ml}, 3 \mathrm{M})$ and solutions dried at $80^{\circ} \mathrm{C}$ for $15 \mathrm{~min}$, during which time any unreacted $\mathrm{H}^{14} \mathrm{CO}_{3}^{-}$was evaporated as ${ }^{14} \mathrm{CO}_{2}$. Ten millilitres of scintillation fluid (0.5\%, w/v, 2,5-diphenyloxazole toluene) was 
added, and the radioactive decay measured on a Packard Tricarb scintillation counter.

NMR spectroscopy. Acetyl-CoA carboxylase activity was investigated employing ${ }^{1} \mathrm{H}-\mathrm{NMR}$, where the fate of specific metabolites could be followed over time. For NMR measurements, lysates, supernatants or membranes were resuspended in $150 \mathrm{mM} \mathrm{NaCl}$ constituted in ${ }^{2} \mathrm{H}_{2} \mathrm{O}$ and dispensed in $5 \mathrm{~mm}$ tubes (Wilmad). Free induction decays were collected using a Bruker AM-500 spectrometer, operating in the Fourier transform mode. Measurements were carried out at $37^{\circ} \mathrm{C}$. Sequential spectra were acquired automatically at $500 \cdot 11 \mathrm{MHz}$ with presaturation of the water resonance.

The instrumental parameters were: spectral width $5434.7 \mathrm{~Hz}$, memory size $8 \mathrm{~K}$, recycling time $3.5 \mathrm{~s}$, number of transients 256 , and pulse angle $50^{\circ}(8 \mu \mathrm{s})$. Exponential filtering of $1 \mathrm{~Hz}$ was applied prior to Fourier transformation. Substrate concentrations for the reaction were: $20 \mathrm{mM}$ acetyl-CoA, $40 \mathrm{mM}$ ATP, $40 \mathrm{mM} \mathrm{NaHCO}_{3}$ and $5 \mathrm{mM} \mathrm{MgCl}_{2}$. Concentrations are different to those used in the radioactive tracer assay as higher levels of assay components are needed to detect and distinguish reactants in an NMR spectrum. The reaction was started by adding $100 \mu \mathrm{l}$ bacterial preparation to a total sample volume of $500 \mu \mathrm{l}$.

The time-evolution of products and utilization of substrates was followed by acquiring sequential spectra. Assignment of resonances was achieved by adding the appropriate metabolite and comparing its spectral position with that of the products in the bacterial preparation.

\section{RESULTS}

\section{Identification and partial purification of a biotinylated protein in $\boldsymbol{H}$. pylori}

After extensive investigation of bacterial extracts, it was found that there was only a single biotinylated product present in $H$. pylori. A high molecular mass biotinylated protein was identified in cell-free extracts of all strains tested. When cell-free extracts were applied to a Sephacryl S-300 HR column, the biotinylated protein was detected in fractions eluted just after the void volume (Fig. 1). Fractions testing positive for this protein by Western

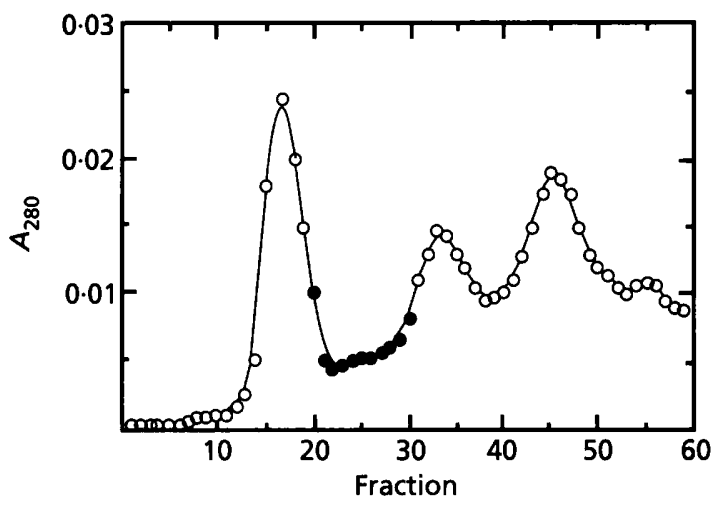

Fig. 1. Elution profile of $H$. pylori cell-free extracts obtained by gel filtration through a Sephacryl column. Proteins were eluted with $100 \mathrm{mM}$ sodium phosphate buffer at a flow rate of $1.2 \mathrm{ml}$ $\mathrm{min}^{-1}$ and detected at $280 \mathrm{~nm}(O)$. . Fractions testing positive for biotinylated proteins.

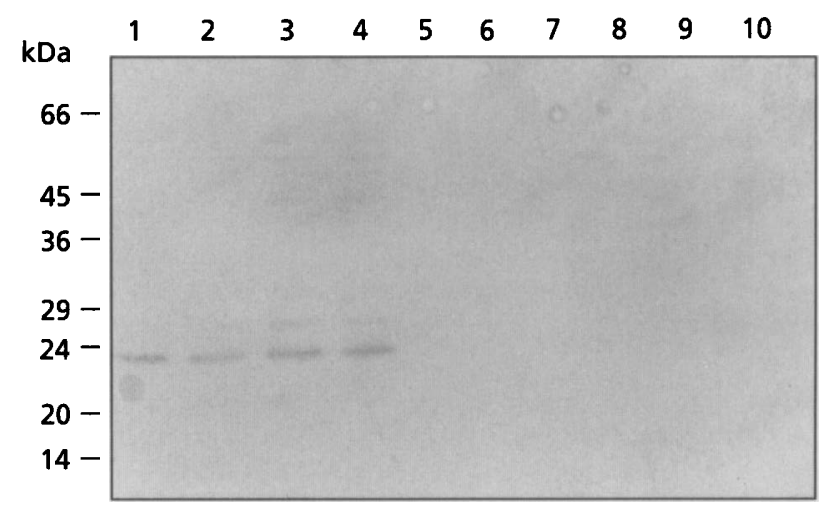

Fig. 2. Size characterization of $H$. pylori biotinylated protein. Samples obtained after membrane filtration were denatured and reduced, then electrophoretically separated using SDSPAGE. The Western blot of this gel was then probed with an avidin-linked conjugate and analysed for the presence of biotin. Lanes: 1 and 2, all soluble proteins; 3 and 4, proteins greater than $100 \mathrm{kDa}$ in size; 5 and 6 , proteins less than $100 \mathrm{kDa} ; 7$ and 8 , proteins $30-100 \mathrm{kDa} ; 9$ and 10 , proteins less than $30 \mathrm{kDa}$.

blotting were subsequently pooled. The biotin-containing protein from this semi-pure extract was further characterized by membrane filtration. SDS-PAGE of the retentate and filtrate and subsequent Western blotting showed that the biotinylated protein was retained only in fractions containing molecules greater than $100 \mathrm{kDa}$ in size (Fig. 2).

Purification of the biotinylated protein using the monomeric avidin column was not successful. It was found that the protein was only partially retarded on the column, and the recovery of protein was poor. Other authors have encountered similar problems in the purification of biotinylated proteins, particularly in relation to the elution of these proteins from avidin columns (Berger \& Wood, 1975; Swack et al., 1978).

\section{Determination of cellular location of acetyl-CoA carboxylase}

When crude cell-free extracts were separated into supernatant and membrane fractions the biotinylated protein was isolated in the soluble fraction. Although the protein was found to be associated with this fraction, it is not known whether the enzyme is cytoplasmic or periplasmic.

\section{Molecular mass determinations}

To determine the molecular mass of the native protein complex, samples were analysed with PAGE under nondenaturing and non-reducing conditions. Attempts to estimate the protein's size by analytical gel filtration were not productive. Gel filtration yielded broad peaks unsuitable for accurate protein size determination (range $\sim 190-280 \mathrm{kDa}$ ). For this reason we opted instead for native PAGE. The presence of a single biotinylated band by this method enabled us to estimate molecular size. 
Table 1. Demonstration of acetyl-CoA and biotin dependencies on acetyl-CoA carboxylase in $\mathrm{H}$. pylori cellfree extracts

The concentrations of assay components were: $1 \mathrm{mM}$ acetylCoA; $10 \mathrm{mM} \mathrm{HCO}_{3}^{-} ; 1 \mathrm{mM} \mathrm{ATP} ; 1 \mathrm{mM} \mathrm{Mg}^{2+} ; 0 \cdot 2 \mathrm{mg} \mathrm{BSA}$. Assay mixtures were incubated at $37^{\circ} \mathrm{C}$ for $60 \mathrm{~min}$. Values are expressed as means of at least duplicates; $100 \%$ activity is equivalent to the carboxylation of $0.307 \mu \mathrm{mol} \mathrm{min}^{-1}$ (mg protein $)^{-1}$.

\begin{tabular}{|lc|}
\hline Conditions & $\begin{array}{c}\text { Carboxylase } \\
\text { activity (\%) }\end{array}$ \\
\hline Complete reaction mixture & 100 \\
Without enzyme extract & $2 \cdot 6$ \\
Without acetyl-CoA & $12 \cdot 4$ \\
With avidin & $6 \cdot 3$ \\
With biotin-saturated avidin & $87 \cdot 9$ \\
\hline
\end{tabular}

From the relative mobility of the enzyme and from those of the standard proteins, a calibration curve was constructed where the native molecular size was estimated at $235 \pm 16 \mathrm{kDa}$. Employing denaturing and reducing SDSPAGE, a biotinylated protein subunit of molecular mass $24 \pm 2 \cdot 1 \mathrm{kDa}$ was obtained (Fig. 2).

\section{Identification of enzyme activity}

Comparisons of the size of the protein complex and subunit in $H$. pylori with known bacterial biotinylated proteins suggested the possibility that the enzyme was acetyl-CoA carboxylase. An acetyl-CoA-dependent carboxylase activity was identified in $H$. pylori extracts (Table 1). Cell-free extracts showed acetyl-CoA carboxylase activity at a rate of $0.285 \pm 0.024 \mu \mathrm{mol}$ product formed $\min ^{-1}$ (mg protein) ${ }^{-1}$, with a linear activity for $75 \mathrm{~min}$ under the experimental conditions employed. The enzyme preparation was incubated for $10 \mathrm{~min}$ with $2 \mathrm{mg}$ avidin $\mathrm{ml}^{-1}$ to determine whether the observed activity was from a biotinylated protein. Catalysis of $\mathrm{H}^{14} \mathrm{CO}_{3}^{-}$was almost completely inhibited when avidin was present in the assay system; however activity was unaffected when avidin was pre-treated with $10 \mathrm{mM}$ biotin (Table 1). These results provided reliable evidence for a biotin-dependent carboxylase activity in $H$. pylori.

\section{End-product identification}

${ }^{1} \mathrm{H}-\mathrm{NMR}$ spectra showing the time-evolution of substrates and products of the acetyl-CoA carboxylase reaction in incubations with $H$. pylori cell-free extracts are shown in Fig. 3. The decrease in the peak of the methyl group of acetyl-CoA and the appearance of a peak corresponding to malonyl-CoA was observed. The assignment of this peak was carried out by comparing its chemical shift with that of malonyl-CoA. Hydrolysis of acetyl-CoA was also present in these preparations (Fig. 3), yielding acetate and $\mathrm{CoA}$ as products. The production of
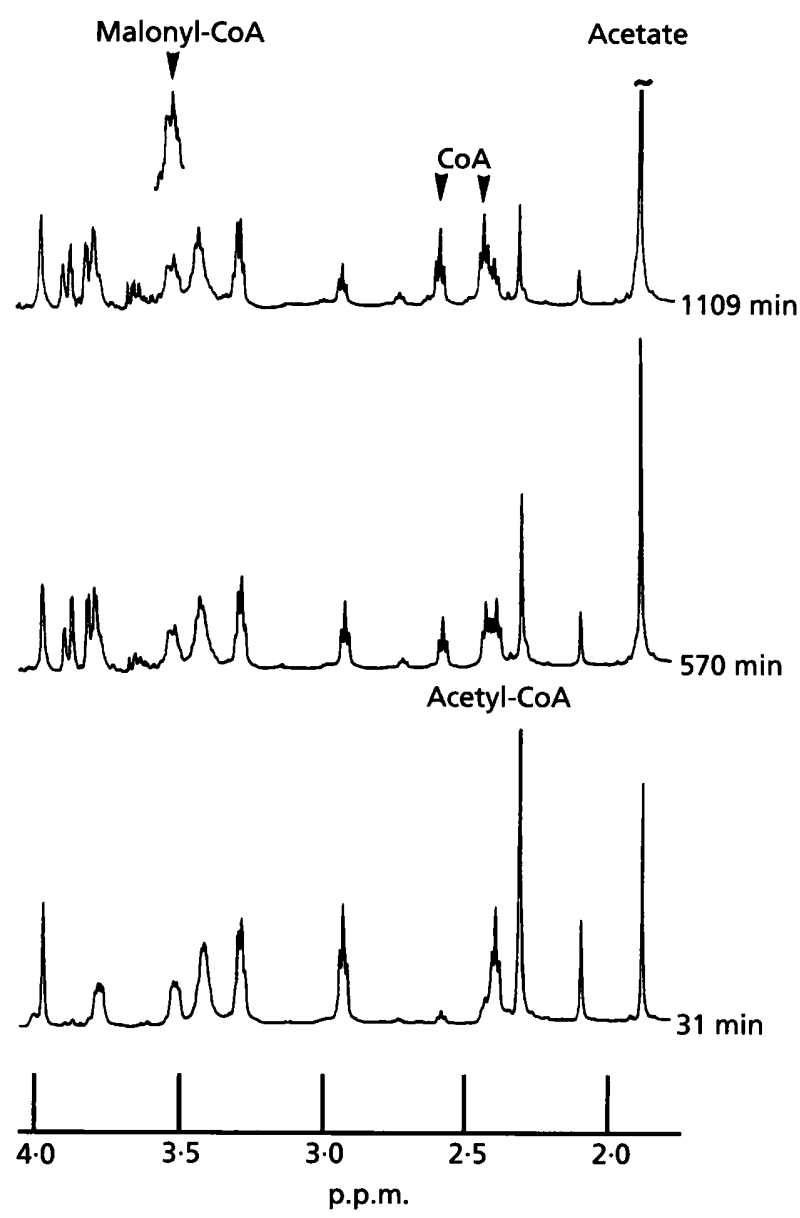

Fig. 3. ${ }^{1} \mathrm{H}-\mathrm{NMR}$ spectra of a time-course of acetyl-CoA carboxylation by $H$. pylori cell-free extracts. The resonances corresponding to the substrate acetyl-COA and the carboxylation product malonyl-COA are indicated on the figure. The inset corresponds to enlargements of the malonyl-CoA peak. Resonances corresponding to free CoA and acetate are also shown. The times at which each spectrum was acquired are shown on the right-hand side.

malonyl-CoA and the hydrolysis of acetyl-CoA was shown to be enzymic and not chemical, as none of these changes were observed when the substrates were incubated without enzyme preparation.

\section{Kinetic studies}

For kinetic analysis, carboxylation of acetyl-CoA was studied over a concentration range of $0.5-50 \mathrm{mM}$ for bicarbonate employing radioactive trace analysis, with both acetyl-CoA and ATP at a concentration of $1 \mathrm{mM}$. The latter substrates were shown to be saturating as no increase in activity was observed when the concentrations were raised to $5 \mathrm{mM}$ and $10 \mathrm{mM}$ for acetyl-CoA and ATP, respectively. The enzyme reaction as a function of bicarbonate concentration was saturable, with a $V_{\max }$ of $0.730 \pm 0.048 \mu \mathrm{mol} \mathrm{min}^{-1}$ (mg protein $)^{-1}$. The apparent $K_{\mathrm{m}}$ value of the enzyme for bicarbonate was at $16 \cdot 6 \pm 2 \cdot 7 \mathrm{mM}$. 


\section{DISCUSSION}

A biotin-containing acetyl-CoA carboxylase system from $H$. pylori has been identified and partially characterized, with the focus on the efficiency of carboxylation. The present investigation utilized the high affinity of avidin for biotin $\left(K_{d}=10^{-15} \mathrm{M}\right.$; Green, 1963) to detect biotinylated enzymes in a heterogeneous population of proteins. In this study, the characteristics of the biotinylated protein in $H$. pylori could be studied in cell-free extracts, as the presence of the enzyme could be detected specifically on a Western blot using an avidin-linked enzyme conjugate. The demonstration of acetyl-CoAdependent enzyme activity and the product formation of malonyl-CoA identified this protein as an acetyl-CoA carboxylase, and a central role for biotin was indicated by avidin-inhibited carboxylase activity.

The acetyl-CoA carboxylases of bacteria are commonly multi-enzyme complexes and not just multi-functional proteins as in the eukaryotic equivalents (Moss \& Lane, 1971). The bacterial enzymes studied to date have been ternary complexes with each component having a distinct function in acetyl-CoA carboxylation. One component is a biotinyl $\mathrm{CO}_{2}$ carrier protein involved in carboxyl transfer between substrates (Knowles, 1989). The demonstration in the present study of a biotinylated protein component of $24 \mathrm{kDa}$ corresponded very well with the molecular mass $(22.5 \mathrm{kDa})$ of the biotinyl $\mathrm{CO}_{2}$ carrier protein of Escherichia coli acetyl-CoA carboxylase described by Guchhait $e$ t al. (1974). It also correlated with the $25 \mathrm{kDa}$ protein associated with acetyl-CoA carboxylase in Pseudomonas citronellolis (Ray \& Fall, 1976). Other similarities were also seen between the native size of the acetyl-CoA carboxylase in E. coli and $H$. pylori. An approximate molecular mass of $235 \mathrm{kDa}$ was measured for the complex in H. pylori, while in E. coli the native complex exhibited a size of $250 \mathrm{kDa}$ (Guchhait et al., 1974). These findings suggest that the $24 \mathrm{kDa}$ biotinylated band visualized in SDS-PAGE preparations of $H$. pylori may be the biotinyl $\mathrm{CO}_{2}$ carrier protein of the acetyl-CoA carboxylase complex.

One feature of the $H$. pylori biotin protein that appeared to be different to $E$. coli is the strength of the interactions between the proteins in the complex. E. coli acetyl-CoA carboxylase is completely dissociated under most purification conditions (Guchhait et al., 1974). It was observed, however, that the complex in H. pylori is relatively stable through most stages of purification, as the protein testing positive for biotin was always retained on the $100 \mathrm{kDa}$ molecular mass cut-off filter (Fig. 2). This result is similar to the finding in Propionibacterium shermanii (Stirling et al., 1981), which also has a relatively stable acetyl-CoA carboxylase.

NMR spectroscopy in this study was employed to support the radioactive tracer analysis data and to identify the endproduct malonyl-CoA. The data showed that acetyl-CoA utilization occurred faster than malonyl-CoA formation. The dramatic reduction in the acetyl-CoA peak can be explained by the cleavage of the high-energy acetyl-CoA bond to form acetate and free CoA, both of which increased in the sequential spectra (Fig. 3). Furthermore, as these results were obtained using cell-free extracts other enzyme reactions may also be occurring. Acetyl-CoA is also required in the next step of fatty acid synthesis in the formation of an acetyl-acyl carrier protein complex (Stryer, 1988), and the presence of phosphotransacetylase in the fermentation of pyruvate has been established previously in H. pylori (Mendz et al., 1994a).

The slow increase in the malonyl-CoA peak could also be attributed to a rapid turn-over of this product as malonyl$\mathrm{CoA}$ is metabolized in the next step of fatty acid synthesis, and is also one of the intermediates in the de novo formation of biotin (Lezius et al., 1963). It is not known whether $H$. pylori has the capability to synthesize its own biotin, and it would be interesting to determine whether the product of a biotin-dependent reaction was involved in the formation of biotin itself. Another enzyme involved in the hydrolysis of malonyl-CoA is a decarboxylase, present in Pseudomonas fluorescens (Hayaishi, 1955), which may also contribute to malonyl-CoA loss if present in H. pylori.

The Michaelis constant of the enzyme for bicarbonate revealed that the enzyme has a very low affinity for bicarbonate. A $K_{\mathrm{m}}$ of $16.6 \mathrm{mM}$ shows that the H. pylori enzyme has a lower affinity for $\mathrm{HCO}_{3}^{-}$than acetyl-CoA carboxylases reported for other micro-organisms: $2.9 \mathrm{mM}$ for E. coli (Guchhait et al., 1974) and $3.0 \mathrm{mM}$ for $P$. shermanii (Stirling et al., 1981). Unlike $H$. pylori, these organisms do not have a requirement for elevated levels of $\mathrm{CO}_{2}$, suggesting that the high $K_{\mathrm{m}}$ is related to the ecological niche of this bacterium.

From an evolutionary point of view, the question arises as to whether in colonizing its ecological niche the bacterium evolved with a low affinity enzyme or developed it as an adaptation to this unique environment. It has been shown that there is a significant amount of $\mathrm{HCO}_{3}^{-}$in the normal gastric mucus (Gamble, 1950), and the activity of $H$. pylori urease may also contribute to an increased availability of bicarbonate (Hazell, 1992). Certainly urease activity appears to be essential for colonization (Eaton et al., 1991). Thus both the host and the bacterium may contribute to the creation of an environment with an increased bicarbonate concentration. In such an in vivo environment acetyl-CoA carboxylase with a low affinity for the substrate may function quite efficiently. Indeed an enzyme with a low affinity for the substrate may be desirable in such circumstances.

In summary, this study has identified the first committed step in de novo fatty acid synthesis in $H$. pylori, and as such the enzyme could be expected to be essential for the organism. In addition, the enzyme was detected in all strains tested, including a low passage clinical isolate, and results from the kinetic experiments suggest that acetylCoA carboxylase of $H$. pylori can carboxylate acetyl-CoA efficiently only at high concentrations of bicarbonate. It is possible that the kinetic characteristics of this enzyme are one of the causes of the requirement of an increased $\mathrm{CO}_{2}$ or bicarbonate environment for growth of $H$. pylori in vitro. To obtain a complete understanding of the role of $\mathrm{CO}_{2} / \mathrm{HCO}_{3}^{-}$in the physiology of the bacterium, it will be 
necessary to study other enzymes in this bacterium that utilize these metabolites.

\section{ACKNOWLEDGEMENTS}

This work was supported by a grant from the Australian National Health and Medical Research Council.

\section{REFERENCES}

Ajl, S. J. \& Werkman, C. H. (1948). Replacement of $\mathrm{CO}_{2}$ in heterotrophic metabolism. Arch Biochem Biopbys 19, 483-492.

Beaty, N. B. \& Lane, M. D. (1982). Acetyl-CoA carboxylase: rapid purification of the chick liver enzyme and steady state kinetic analysis of the carboxylase-catalysed reaction. $J$ Biol Chem 257, 924-929.

Berger, M. \& Wood, H. G. (1975). Purification of the subunits of transcarboxylase by affinity chromatography on avidin-sepharose. $J$ Biol Chem 250, 927-933.

Burns, B. P., Hazell, S. L. \& Mendz, G. L. (1994). Identification of a biotinylated protein in Helicobacter pylori. Aust Microbiol 15, A97.

Cox, D. L. \& Baugh, C. L. (1977). Carboxylation of phosphoenolpyruvate by extracts of Neisseria gonorrboeae. J Bacteriol 129, 202-206.

Eaton, K. A., Morgan, D. R., Brooks, C. L. \& Krakowka, S. (1991). Essential tole of urease in the pathogenesis of gastritis induced by Helicobacter pylori in gnotobiotic piglets. Infect Immun 89, 2470-2479.

Gamble, J. L. (1950). Chemical Anatomy, Physiology and Patbology of Extracellular Fluid, 5th edn. Cambridge: Harvard University Press.

Goodwin, C. S., Armstrong, J. A. \& Marshall, B. J. (1986). Campylobacter pyloridis, gastritis and peptic ulceration. J Clin Patbol 39, 353-365.

Gravel, R. A., Lam, K. F., Mahuran, D. \& Kronis, A. (1980). Purification of human liver propionyl-CoA carboxylase by carbon tetrachloride extraction and monomeric avidin affinity chromatography. Arch Biochem Biophys 201, 669-673.

Green, N. M. (1963). Avidin: the nature of the biotin binding site. Biocbem J 89, 599-609.

Gregolin, C., Ryder, E., Kleinschmidt, A. K., Warner, R. C. \& Lane, M. D. (1966). Molecular characteristics of liver acetyl-CoA carboxylase. Biochemistry 56, 148-155.

Guchhait, R. B., Polakis, S. E., Dimroth, P., Stoll, E., Moss, J. \& Lane, M. D. (1974). Acetyl coenzyme A carboxylase system of Escherichia coli. J Biol Chem 249, 6633-6645.

Hayaishi, O. (1955). Enzymatic decarboxylation of malonic acid. $J$ Biol Chem 215, 125-136.

Hazell, S. L. (1992). The role of Helicobacter pylori urease: a contentious issue. Eur J Gastroenterol Hepatol 4 (Suppl 1), S55-S59.

IARC (1994). Schistosomes, liver fluke and Helicobacter pylori. I ARC Monographs on the Evaluation of Carcinogen Risks to Humans, vol. 61, pp. 177-240. Lyon: International Agency for Research on Cancer, World Health Organization.

Knowles, J. R. (1989). The mechanism of biotin dependent enzymes. Annu Rev Biocbem 58, 195-221.

Laemmli, U. K. (1970). Cleavage of structural proteins during the assembly of the head of bacteriophage T4. Nature 227, 680-685.

Lezius, A., Ringelman, E. \& Lynen, F. (1963). Zur biochemischen Funktion des Biotins IV. Die Biosynthese des Biotins. Biochem $Z$ 336, 510-525.

Lyman, C. M., Moseley, O., Wood, S., Butler, B. \& Hale, F. (1947). Some chemical factors which influence the amino acid requirements of the lactic acid bacteria. J Biol Chem 167, 177-187.

Marshall, B. J. \& Warren, J. R. (1984). Unidentified curved bacilli in the stomach of patients with gastritis and peptic ulceration. Lancet i, 1311-1315.

Mendz, G. L., Hazell, S. L. \& van Gorkum, L. (1994a). Pyruvate metabolism in Helicobacter pylori. Arch Microbiol 162, 187-192.

Mendz, G. L., Jimenez, B. M., Hazell, S. L., Gero, A. M. \& O'Sullivan, W. J. (1994b). De novo synthesis of pyrimidine nucleotides by Helicobacter pylori. J Appl Bacteriol 77, 1-8.

Moss, J. \& Lane, M. D. (1971). The biotin-dependent enzymes. $A d v$ Enzymol 35, 321-442.

Nedenskov, P. (1994). Nutritional requirements for growth of Helicobacter pylori. Appl Environ Microbiol 60, 3450-3453.

Neilan, B. A., Leigh, D. A., Rapley, E. \& McDonald, B. L. (1994). Microsatellite genome screening: rapid non-denaturing, nonisotopic dinucleotide analysis. Biotechniques 17, 708-712.

Ray, R. \& Fall, M. (1976). Stabilisation of an acetyl coenzyme A complex from Pseudomonas citronellolis. Biochem Biophys Acta 450, 475-480.

Reynolds, D. J. \& Penn, C. W. (1994). Characteristics of Helicobacter pylori growth in a defined medium and determination of its amino acid requirements. Microbiology 140, 2649-2656.

Stirling, L. A., Ahmad, P. M. \& Ahmad, F. (1981). Acyl coenzyme A carboxylase of Propionibacterium shermanii: detection and properties. $J$ Bacteriol 148, 933-940.

Stryer, L. (1988). Biochemistry, 3rd edn. New York: W. H. Freeman. Swack, J. A., Zander, G. L. \& Utter, M. F. (1978). Use of avidinsepharose to isolate and identify biotin polypeptides from crude extracts. Anal Biochem 87, 114-126.

Towbin, H., Staehelin, T. \& Gordon, J. (1979). Electrophoretic transfer of proteins from polyacrylamide gels to nitrocellulose sheets: procedure and some applications. Proc Natl Acad Sci USA 76, 4350-4354.

Received 22 March 1995; revised 17 August 1995; accepted 23 August 1995. 